\title{
A Review of the Geographical Research of Isolation and Separation Features of the Balkan Peoples and States in the Time of Cvijić and Today
}

\author{
Dejan Šabić*, Snežana Vujadinović \\ Faculty of Geography, University of Belgrade, Serbia
}

Copyright $\bigcirc 2017$ by authors, all rights reserved. Authors agree that this article remains permanently open access under the terms of the Creative Commons Attribution License 4.0 International License

\begin{abstract}
The Balkan Peninsula is a geographical region where different civilizations meet and permeate, but also a region of isolation and separation of its peoples. Its territory was the place where the interests of the great economic and political powers often collided and merged, mostly for political and military reasons. The historical processes that marked the last decade of the 20th century on the Balkan Peninsula were not in accordance with the integration processes in Europe, which took place after the Second World War, and whose intensity heightened after the fall of the Berlin Wall and the reunification of the two parts of Germany. Most nations in the region were not economically and politically ready to accept social changes in Europe and therefore remained isolated and separated in most cases. The article focuses on the geographical research of the isolation and separation features of the Balkan peoples and the states in the time of Jovan Cvijić and nowadays, through the prism of contemporary political and economic processes.
\end{abstract}

Keywords The Balkans, Isolation and Separation Features, Integration Processes

\section{Introduction}

The Balkan Peninsula is a natural link between Europe, Asia and Africa. The traffic routes running horizontally and vertically through river valleys are of great communication and strategic importance as they connect Central Europe and Asia Minor via the Balkans. "Thus have the Rivers Morava and Vardar become the internal centre of the peninsula, arranging the geopolitical space of the Balkans" (Grčić, 2008).

The Balkan Peninsula has been the object of study for geographers, politicians, and historians, because of its geographical location, its multi-ethnic, multilinguistic and multicultural mosaic, economic and political processes. In economic and political terms, the Balkans history has been marked by divisiveness, conflicts and migrations. According to its political features, the Balkans differs from the rest of Europe, where the war as a means of achieving national interests has been outdated since the Second World War. Most of the Balkan states are facing diverse problems resulting from political and economic reforms, the aims of which are to modernize these fundamentally autarchic societies. The last decade of the 20th century was marked by the process of globalization, which "forced" the Balkan states and regions to transform themselves from more or less isolated into the "open" ones so as to be able to join European and global political, economic and cultural trends (Šabic et al., 2015, Bechev, 2006).

\section{Materials and Methods}

This paper presents an analysis of the facts related to the features of isolation and separation of the Balkan peoples and states, with an emphasis on political, economic and cultural issues in the time of Cvijić and today. For that purpose, the most important works of Jovan Cvijić were used, as well as the internet research of publicly available relevant reports and materials of official authorities and interest groups, in different ways related to the issues of political, economic and cultural development of the Balkans. The research process also included a review of the press articles dealing with the Cvijić's research of the Balkans.

In the Western world, state institutions gradually evolved in order to become modern forms which work effectively today. The first attempts to build modern institutions in the Balkan states began in 1990. Deep reforms were introduced to the centrally planned economy, but without much success because the former Yugoslavia and other Balkan states were in debts. A boost to reforms was given by the fall of the Berlin wall and the collapse of socialism in Central and South East Europe countries (Gowan, 1995). 
According to Šabić et al. (2015), a modern political order developing under the conditions of global relations in the world differs from the conditions that existed previously in the period of the Cold War. It was only about 500 years ago, that Columbus' map of the world, before the discovery of America, was mainly blank and marked as Terra incognita. Today European societies, separated as oases in deserts, form, through numerous connections a related system of global values, which is intertwined with political, economic and cultural interests. In his acclaimed book from 1922 "The Balkan Peninsula and the South Slavic countries" Jovan Cvijić indicates that, despite the fact that on the territory of the Balkan states contacts and influences of diverse civilizations converge, the processes of isolation and separation of their people's exist simultaneously.

Recent regional initiatives have served as an instrument of cooperation between the Balkan countries. The ideas of multilateral cooperation in the Balkans in the past were not unprompted, but often a manifestation of a broader international situation. Between 1913 and 1990, there were only two meetings of all Balkan states at the Balkans Conferences (1930-1933) and Foreign Ministers' Conferences (1988-1990). Bilateral contracts were concluded between Romania and Greece and Romania and Turkey (1928), Yugoslavia and Greece (1929) and Greece and Turkey (1930), then again Greece and Turkey and Yugoslavia and Turkey (1933). The First Conference took place in Athens in 1930, the Second in Istanbul and Ankara in 1931, the Third in Bucharest in 1932 and the Fourth in Thessaloniki in 1934 (Stojković, 1998).

Two decades ago, global integration processes were a distant idea for the Balkan states and peoples. By the middle of the second decade of the 21 st century, these processes started to shape the political, economic and cultural life of the Balkan states more intensively. Multinational companies in their search for the most favourable terms of doing business and making profit, cheap labour force and resources are traversing the world and bringing about changes in the Balkans (Bechev, 2006). Transnational economic powers are demonstrating more and more domination over local and national economies in the region. Information and media messages are crossing the boundaries of the Balkan Peninsula and reshaping the geographic area Cvijić (1922) wrote about in his "The Balkan Peninsula and the South Slavic countries".

Globalization creates opportunities for linking national economies and expanding national markets, but it also increases economic and social vulnerability of the Balkan states. In terms of culture, globalization allows meeting different cultures on one hand, while on the other it creates uniformity of cultural values. In such circumstances there is a risk of rejecting one's own culture for the sake of accepting global monoculture (Šabić and Vujadinović, 2014; Božilović, 2003; Bartlett and Prica, 2011). As every kind of isolation from global flows is harmful, it is equally detrimental to apply blindly the instruments of global economic, political and cultural homogeneity that can impoverish national economies. Unfortunately, this type of globalization is largely implemented in each Balkan state. They have their natural and social specific features on which they develop and build their social and political systems. In these processes of globalization the Balkan states should accept only what leads to strengthening of their own economies but also to improving and strengthening relations with neighbouring states (Šabić, 2011; Šabić et al., 2015; Anastasakis et al., 2002).

\section{Results and Discussion}

\subsection{Geographical Interpretations of Certain Features of the Balkan Peninsula in the Time of Cvijić and Today}

The field studies of Jovan Cvijić were aimed at determining the scientific truth about natural, demographic and ethno cultural characteristics of the Balkans. They were performed in the time of really scarce literature on this economically and politically backward part of Europe, that had just been set free from the Turkish rule. His works can therefore be characterised his as ground-breaking, but also as visionary since certain stated facts still apply to this area.

Cvijić (1922) states that geographical conditions, especially high mountains, were "massive bars" that caused nations "to divide and thus weaken and exhaust". He also states that "... human groups that inhabited isolated areas stayed closed and had, to a certain point, distinct development, which is different from the development of other groups residing in the areas of mergers and permeation on the Balkans... Numerous geographical factors are the cause of separation... Even small rivers with low but marshy banks, prevent human movement and present border lines between certain ethnic groups in the Balkans. This role is even more evident with rivers, whose valleys are deep and steep-sided, such as Morača, Piva and Tara canyons that divide mountainous tribes of the Montenegrin Hills ... "Unfortunately, according to Šabić et al. (2015), even today one can conclude that some of the Balkan rivers present borders that separate the same or different nations, as is the case with the Drina and Ibar rivers in Kosovo.

Mountains and marshy valleys, as stated by Cvijić (1922), "especially when they are covered by dense forests present considerable obstacles to traffic. Medieval roads, which were used by caravans, avoided marshy valleys and gorges, and went along the mountain sides and ridges ... Roman roads rarely avoided gorges and valleys "and linked villages and provinces. Modern roads - regional, motorways and highways follow their routes today in the region. The most important Roman road was the Military Road (lat. Via Militaris), which led from Belgrade (Singidunum) through Požarevac (Viminatium), Niš (Naissus), Sofia (Serdica), Edirne (Hadrianopolis) all the way to Constantinople. This road was linked with Egnatia Road (lat. Via Egnatia) through the Vardar Valley in the southern part of the Balkan 
Peninsula. In the middle Ages, the Constantinople Road was one of the most important roads in the Balkans, which connected Belgrade to Istanbul. Today, the main regional road E-80 follows this route, the eastern branch of the Corridor 10 (Salzburg - Zagreb - Belgrade - Niš - Sofia Istanbul). The unity of the Roman Empire was based on the organized administrative, military and transport infrastructure. Transport links, as Bordman points out (1999), made it possible for the largest part of the Balkan Peninsula, which was under the Roman Empire, to be integrated into a common set of legal norms. Geopolitical instrument for conquering and later protecting the Roman Empire was the limes (lat. Limes). The term limes was originally used for roads in less accessible regions, and in the last centuries of the Roman Empire it became the transitional zone between the empire and barbarians, between the law and arbitrariness. The most famous example of the Roman limes on the Balkan Peninsula was Moesian limes (lat. Limes Moesiae) on the Danube. Historical circumstances have changed and today the Danube presents a factor of integration and cohesion of the Danubian countries. Corridor 7 or the Danube pan-European corridor is one of the most important European routes, which together with the Rhine and Main forms the most important waterway in the continent.

Cvijić (1922) states that "the greatest obstacle to human movement in the past, and thus a constant factor of isolation and separation, were mountain ranges composed of more ridges and high plateaus, separated by valleys or deep, closed depressions. Of the same importance are mountainous areas divided into numerous isolated basins ... ". Cvijić also says that the Dinaric Arc was unable to prevent the Serbs and Croats "to settle all over it. Mountain ranges do not resist ethnic penetration as much as ethnic movements arising from human activities and the currents of civilization." Centralni Balkan (The Central Balkan) and Srednja Gora (the Central Hill) did not prevent the Bulgarians to cross over from one side to the other, but divide northern areas with patriarchal and Turkish-Oriental regime from Southern areas with strong traces of the old Byzantine civilization. A typical example of isolation in modern circumstances, "separation into regions", as stated by Cvijić (1922), is the Pomaks in Bulgaria. These are the Bulgarians of the Islamic faith who live mostly in Pazardzhik and Blagoevgrad. They preserved many archaic elements, which they acquired during the period of Turkish-Oriental influences on their language, material and spiritual culture due to the isolating way of life. Similar situation can be found with Torbeshi, an ethnic group of Macedonians, whose members accepted Islam during the Ottoman rule, like the Pomaks in Bulgaria. Unlike the Pomaks and Torbeshis, Goranci present an ethnic community that embraced Islam in the 16th century but preserved many Slovene customs (Šabić et al. 2015).

Mountain massifs as Cvijić (1922) emphasized led to the situation in which "the population remained more or less isolated. These massifs look like huge islands, around which historic waves and currents of civilization crashed, like silent and secluded shelters for protecting population that fled from turmoil's of successive invasions. The old Balkan livestock herding, shepards' movements and some old crafts have been preserved and developed in the most original form here, as well as the clearest forms of patriarchal life and tribal organization ... It was difficult for the Turks to penetrate into the interior of the Dinara massif, because these were peripheral areas for them, far away from Constantinople, and in them Turkish influences were the weakest." Some parts of the Balkans, such as the Montenegrin hills and regions, a real mountainous and karst fortress, remained almost completely isolated, and in social terms behaved as islands..." (Cvijić, 1922). From today's point of view, Cvijić's claims are evident in the typical example of the inhabitants of the mountainous part of Montenegro, who have still kept the characteristics of tribal affiliations and segments of traditional way of life.

Judging by the traces left by ancient people, who survived in the mountainous massifs of the Balkans, but are disappearing nowadays, "we can trace down various stages of ethnic assimilations that had previously occurred on the peninsula. Here, as almost everywhere in mountainous areas, the most resistant bases of autonomous and independent life of free highlanders had their roots and kept surviving" or of parishioners, as is the case with the Goranci in southern Kosovo (Cvijić, 1922). Despite the cultural and political influence of the Albanian population, they managed to maintain their ethnic and cultural identity and resist assimilation until today. Cvijić (1922) pointed out that the Adriatic coast in Albania, mainly marshy, did not attract migratory currents in the past. This is one of the main causes why the Albanians preserved their ethnic identity and remained from ancient times until today in this region. Unlike the Albanians, the central part of the Balkan mountain and Srednja Gora (the Central Hill) in Bulgaria evidenced assimilations in the past. There, as Cvijić writes (1922), in the middle Ages the Aromanians or Vlachs, who rebelled against the Byzantine Empire and formed a Vlach-Bulgarian Empire, withdrew. However, during the following centuries, they became completely assimilated by the Bulgarians. Very few traces of Vlach-Bulgarian origin were preserved in anthropological types and psychological characteristics.

While studying the Balkans, Cvijić used to emphasize that through history its mountainous valley basins had always been the starting point of migration currents, which for themselves had been a constant factor of integration and permeation.

Cvijić expected that the joint life of Yugoslav nations would be troublesome in view of their different ways of life, mentality, historical and cultural specificities on the one hand and numerous natural factors on the other hand. He saw political and intellectual figures as advocates of the Balkan unity. In regard to the common state, he remained consistent to the idea that "the vast majority feels spiritual, moral and material benefits of community and unity"(Mulin, 1927).

Migrations have been in the focus of scientific research since the time of Cvijić. Regardless of their causes and 
consequences, migrations marked different historical periods of the Balkans and largely redefined its spatial and functional organization, its settlement and demographic features. Following current political and economic trends in Europe the character of migrations in the Balkan area has been gaining a different dimension. Intense forced migrations, combined with economic migrations are typical for the period of disintegration of socialist systems in Central and Eastern Europe and the cause of outbreak of the Balkan wars. Serbia faced great challenges at the time as it had become a country of refuge, transit and origin of many people who for various reasons had to leave their homes. In 2011 in Serbia there were 30,000 registered refugees and 210,000 internally displaced persons from Kosovo (Vujadinović et al., 2013, Šabić et al., 2012). A unique phenomenon of exile is its cultural specific feature that was reflected in the "conflict" of urban and rural way of life, which often acquired forms of social intolerance. Local political structures manipulated with the destiny of refugees. They would treat the refugees as patriots at one point, then at another as victims and heroes. For this reason, many urban areas showed utter reticence and restraint towards the wave of refugees since allegedly the city lifestyle was "threatened" by refugees. The media reflected political, economic and cultural aspects of the new situation. Over time, with the calming of the political and security situation in the region, the above-mentioned tensions weakened, which is evidenced in the fact that the majority of refugees expressed a desire to continue living in Serbia. This made the integration of refugees a constant challenge for the state and local authorities and gave it even more importance in the years to come (Šabić et al. 2015).

Serbia has long been a transit country for a large number of illegal migrants on their way to Western Europe. Although Serbia is just a transit point for most of them, the question of adequate accommodation of these asylum seekers in times of an economic crisis presents a major challenge for the country. In contrast, the emigration movements from Serbia during the war years and asylum seekers marked the 1990s. In the first decade of the 21 st century, Serbia was among the top five states in the world in the number of asylum seekers in European states. A large number of failed asylum seekers from Serbia, who were sent back to Serbia in accordance with the Law on readmission, brought additional strain on the state (Vujadinović et al., 2011). The wars in Afghanistan, Iraq, Syria and other Muslim countries, as well as the rise of the so-called Islamic State, have led to the largest migrant crisis around the world, especially in Europe during the summer and autumn of 2015. Most migrants have arrived in Europe via the Balkan route across Turkey, Greece, the Former Yugoslav Republic of Macedonia and Serbia to Croatia and Hungary. In September/ October 2015, Hungary closed the state borders with Serbia and Croatia, so the majority of the refugee wave moved towards Croatia. The moves of some EU Member States led to a humanitarian crisis in Greece as the Balkan states closed their borders for the influx of migrants. The Balkan Route officially closed in March 2016 by the EU-Turkey Agreement on the control and curbing of the mass influx of refugees and migrants. This was the second time in recent history that the Balkan states had become a transit space for many people who had to leave their homes.

Unlike migrations resulting from the political instability and wars, there is a much longer continuity of migrations initiated by the industrialization of this area. Especially since the 1960s, there have been both extensive and less extensive migrations of working age population from the mountainous areas into lowland areas, or more precisely into towns and cities. Due to its favourable traffic and geographical position and functions, settlements in valleys and ravines of lowland parts of the Balkan Peninsula still present the areas with more intense economic transformation, while settlements in the mountainous parts almost always have the most unfavourable demographic features and present a relatively homogenous agrarian region. This process was intensified in the 1980 s, and since the 1990 s, there have been migrations from urban settlements - to the city - the capital city or the gravitational centre of the country. The typical examples of this are Athens, where one third of the population of Greece lives or the capitals of the former Yugoslav republics that attract people from all parts of the country intensively, regardless of whether they are villages, towns or cities. What is common to all Balkan states is the consequence of these migrations - rural depopulation, especially in mountainous areas. Unlike mass migration of dominant population in some Balkan states, small ethnic groups still continue to isolate and separate, as the examples of Torbeshi, Pomaks and Goranci can show. Cvijić (1922) pointed out that "returning to the patriarchal conditions, they created their own civilization...".

\subsection{The Importance of Regional Cooperation in the Balkans}

The issues of economic cooperation in the Balkans had been pushed aside for decades. The analysts most often mention the following reasons for such poor cooperation: the absence of a tradition of cooperation, underdevelopment and varying degrees of limited resources, unresolved regional conflicts, including disputes relating to the status and rights of national minorities, emphasized differences in terms of political and economic interests and peripheral position of the Balkans in relation to the major centres of integration in Europe.

At the beginning of the $21^{\text {st }}$ century, the Eastern Balkans singled out as part of the Western economic and military-political structures and the Western Balkans still remained an economic and geopolitical subcontinent of Europe (Grčić, 2005; Balfour and Stratulat, 2011).The Western Balkans remained a heterogeneous spacein economic and political terms. In economic terms, it is still the least developed part of Europe. The common characteristics of all Balkan states are the issues of structural development, since all the countries have been burdened by the legacy of a planned economy for a long time. 
In the 1990s, the Balkan states drifted apart as a result of war conflicts whereas the economic shock therapy, most often suspicious privatisations weakened the competitiveness of the countries in the world economic market. Consequently, regional cooperation is essential to recuperate the Western Balkan countries economically. It should contribute to spatial integration, accelerate economic and social development of the countries and reduce the development gap between the west and east, north and south of the European continent (Magen, 2007). The signing of the Dayton Agreement in 1995 was significant for the stabilization in the region. At the end of 2000, the change of political regimes in Belgrade created the conditions for improvement of mutual relations of the countries in the region and for development of regional cooperation in the Balkans.

At the beginning of the $21^{\text {st }}$ century, the Balkans had still not reached the expected level of integration, but it had managed to distance itself from the stereotypical "powder keg" metaphor, as a region of typical political instability. At the same time, the Balkan states agree on one issue - rapid EU integration. The positive changes are obvious in view of bilateral and multilateral relations at institutional level, their economic cooperation etc. Progress is noticeable in political, economic and administrative reforms, while the least progress was made in the field of law, institutions, corruption and nationalism (Lovčanski, 2005). In fact, apart from the evident progress, the whole region is still often criticised for the inadequate functioning of democratic institutions and division of powers at all levels, respect of human rights, fight against organised crime and corruption. For the first time in their history, Balkan states are defining the same or common goals and interests - European and Euro-Atlantic integrations (Balfour and Stratulat, 2013).

Table 1. Real GDP growth in Western Balkans, \% (World Bank Group, 2016)

\begin{tabular}{|c|c|c|c|c|c|c|c|}
\hline & 2012 & 2013 & 2014 & $2015^{\mathrm{f}}$ & $2016^{\mathrm{f}}$ & $2017^{\mathrm{f}}$ & $2018^{\mathrm{f}}$ \\
\hline Albania & 1.4 & 1.0 & 1.8 & 2.8 & 3.2 & 3.5 & 3.5 \\
\hline Bosnia and Herzeg. & -0.9 & 2.4 & 1.1 & 3.0 & 2.8 & 3.2 & 3.7 \\
\hline Kosovo* & 2.8 & 3.4 & 1.2 & 3.9 & 3.6 & 3.9 & 3.7 \\
\hline Macedonia, FYR & -0.5 & 2.9 & 3.5 & 3.7 & 2.0 & 3.3 & 3.7 \\
\hline Montenegro & -2.7 & 3.5 & 1.8 & 3.2 & 3.2 & 3.6 & 3.0 \\
\hline Serbia & -1.0 & 2.6 & -1.8 & 0.7 & 2.5 & 2.8 & 3.5 \\
\hline
\end{tabular}

Table 2. Public debt in Western Balkans, \% of GDP (World Bank Group, 2016)

\begin{tabular}{|c|c|c|c|c|c|c|c|}
\hline & 2012 & 2013 & 2014 & $2015^{\mathrm{f}}$ & $2016^{\mathrm{f}}$ & $2017^{\mathrm{f}}$ & $2018^{\mathrm{f}}$ \\
\hline Albania & 58.1 & 66.6 & 68.0 & 68.6 & 67.6 & 65.5 & 64.8 \\
\hline Bosnia and Herzeg. & 36.6 & 37.7 & 41.8 & 41.9 & 41.5 & 39.7 & 37.4 \\
\hline Kosovo* & 6.9 & 7.8 & 9.4 & 11.9 & 13.1 & 14.7 & 16.2 \\
\hline Macedonia, FYR & 33.7 & 34.2 & 38.2 & 37.9 & 40.8 & 42.7 & 43.9 \\
\hline Montenegro & 65.4 & 66.8 & 68.8 & 68.1 & 72.3 & 76.4 & 78.6 \\
\hline Serbia & 41.6 & 44.3 & 48.4 & 49.7 & 51.1 & 51.7 & 52.3 \\
\hline
\end{tabular}

Table 3. Trade balance in Western Balkans, \% of GDP (World Bank Group, 2016)

\begin{tabular}{|c|c|c|c|c|c|c|c|}
\hline & 2012 & 2013 & 2014 & $2015^{\mathrm{f}}$ & $2016^{\mathrm{f}}$ & $2017^{\mathrm{f}}$ & $2018^{\mathrm{f}}$ \\
\hline Albania & -18.0 & -17.5 & -20.9 & -18.2 & -20.8 & -21.6 & -21.9 \\
\hline Bosnia and Herzeg. & -24.0 & -20.8 & -22.7 & -19.2 & -17.3 & -17.2 & -17.7 \\
\hline Kosovo* & -34.3 & -31.7 & -31.0 & -30.4 & -31.7 & -32.1 & -32.9 \\
\hline Macedonia, FYR & -22.4 & -18.3 & -17.6 & -16.3 & -16.4 & -16.3 & -15.9 \\
\hline Montenegro & -17.5 & -11.2 & -10.9 & -9.9 & -8.2 & -7.7 & -7.2 \\
\hline Serbia & -20.9 & -16.7 & -17.3 & -15.6 & -15.2 & -15.1 & -15.2 \\
\hline
\end{tabular}


Table 4. Unemployment rate in Western Balkans, \% (World Bank Group, 2016)

\begin{tabular}{|c|c|c|c|c|c|c|c|}
\hline & 2012 & 2013 & 2014 & $2015^{\mathrm{f}}$ & $2016^{\mathrm{f}}$ & $2017^{\mathrm{f}}$ & $2018^{\mathrm{f}}$ \\
\hline Albania & 13.4 & 16.0 & 17.5 & 17.1 & 16.8 & 16.6 & 16.5 \\
\hline Bosnia and Herzeg. & 28.1 & 27.5 & 27.5 & 27.7 & 25.4 & n.a. & n.a. \\
\hline Kosovo* & 30.9 & 30.0 & 35.3 & 32.9 & 32.9 & 35.3 & 35.3 \\
\hline Macedonia, FYR & 31.0 & 29.0 & 28.0 & 26.1 & 24.8 & 23.9 & 22.7 \\
\hline Montenegro & 19.8 & 19.5 & 18.0 & 17.6 & 17.8 & 17.8 & 17.5 \\
\hline Serbia & 24.0 & 22.1 & 19.2 & 17.7 & 16.8 & 15.9 & 16.9 \\
\hline
\end{tabular}

The biggest challenge in the integration of the Balkans into the European Union is the safety and stability of the region, which is in the interest of both the Balkan states and the European Union. The rapprochement process of the Western Balkans with the EU is being carried out through institutional and functional integrations. A precondition for achieving this goal is the intensification of mutual economic connections and improvement in regional cooperation. In this regard, the regional cooperation between the Balkan countries is a test of their readiness to become an integral part of a far complex whole such as the European Union (Anastasakis et al., 2002).

Economic cooperation is the basis for deeper integrations, which can be confirmed by the experience of united Europe. Most Balkan countries have focused politically and economically on the cooperation with the countries of Western and Central Europe. Due to their insufficient economic development, the Balkan countries are not in a position to cooperate with economically developed countries on the basis of equal economic conditions. Trade is an especially important part of that cooperation, with the European Union in particular, as it is more significant that the trade between the Balkan countries (Popescu Nescseti, 1994). The common feature of the Balkans is a low level of trade connections, so the share the regional trade in the overall trade of the Balkan states does not often exceed $5 \%$.

The former Yugoslav republics are nevertheless exceptions to this as there are significant trade flows among them (Popović, 2006). A low level of trade connections, which is one of the more serious problems of the Balkans, led to numerous bilateral agreements on free trade in the region. These agreements were aimed at increasing their mutual economic integrations and integrations of the Balkans with the EU and the world (Balfour and Stratulat, 2013). Through a free flow of people, goods, capital and services, trade liberalization is also expected indirectly to improve economic development of the Balkans, create conditions for the Balkan states to attract foreign direct investment and increase competitiveness and thereby the efficacy of the national economies (Estrin and Uvalić, 2013).

Improving trade relations will enable consumers in the region an access to cheaper and better quality products. The trade benefits arisen from opening the Union market and abolishing the customs duties have not been fully used. The Balkan countries have not increased the export to the EU market due to their underdevelopment, poor competitiveness and non-compliance of their goods and services with the standards and quality of the EU. The unstable market and a business environment unattractive for investors are aggravating circumstances (Bartlett and Prica, 2011). Apart from trade, the Balkan countries have a favourable cooperation predisposition in the areas of transport, agriculture, tourism, energy, cross border cooperation, joint investment, issues of national minorities, fight against organised crime etc. The first order transit route that connects Western Europe with the Middle East and North Europe with Africa goes through the Balkans. The state of transport roads imposes a need for a joint policy in the field of construction, modernisation and use of large roads as the backbone of the transport system of the Balkans.

\subsection{Regional Initiatives}

The delay of the Balkans in the field of regional cooperation was partly compensated for in the late 20th and early 21 st century, by the formation of new initiatives and forms of multilateral regional cooperation (Lopandić, 2007; Uvalić, 2009). Most modern initiatives of multilateral cooperation in the Balkans were created on the experience of the European Union. This is a neo functional theory on multilateral cooperation according to which countries cooperate only in those fields and to the extent agreed on by all members (Veremis, 1993). The initial assumption of the theory was that different forms of technical cooperation between the countries (state administration or political representatives) create a ripple effect on the climate in the region and favourable conditions for integration in the economic area over time (Lopandić, 1999).The main reasons that initiated the cooperation in the Balkans were economic and political rapprochement with the EU, and other forms of European integrations, external pressures (by the EU and other relevant actors of the international community, with the aim of establishing a more intimate and intense cooperation between the Balkan countries, joint problems (narrowness of the national market, economic underdevelopment, high unemployment, corruption) and interdependence of neighbours. The above-mentioned reasons increased the need for integrations and were reinforced by the disintegration of Yugoslavia and the occurrence of the new political situation in the Balkans. In recent years, there were many political, security and economic initiatives introduced with the aim of helping the countries in the region to 
establish stability, dialogue and cooperation. NATO, OEBS, $\mathrm{EU}$ and the Council of Europe as the leading institutions of the Euro-Atlantic area had key roles in launching these initiatives.

The first wave of modern regional initiatives occurred in the late 1980s and during the 1990s, as a result of the dissolution of the Eastern Bloc. In the period between 1988 and 1992, the Central European Initiative, Black Sea Economic Cooperation, the Agreement on Free Trade in Central Europe - CEFTA and others were created. The second wave of modern regional institutions started with the disintegration of Yugoslavia and the end of the war in Bosnia and Herzegovina and in Kosovo: the Cooperation Process in South-East Europe, South-East Europe Cooperative Initiative - SECI, Stability Pact for South-East Europe, Adriatic-Ionian initiative etc.

\section{Conclusions}

Current conditions and importance of the processes of mergers and divisions of Balkan peoples have not diminished since the time of Cvijić. Even in the 21 st century, the Balkan Peninsula is often regarded in Western scientific and political circles as the scene where civilizations clash. This region has long been known as the zone of conflicts in which ethnic relations and cultural identities alternated. Hence the ambivalence in regard to the Balkans exists - from the bridge, the cradle and umbilical cord of Europe, to the unknown world, the damned yard and the powder keg (Stojanović, 1995). The strategic position of the Balkan Peninsula, composed by natural resources (ores, waters, forests, soils) has always caused the region to be in the sphere of interests of great powers. Cvijić pointed out that the fragmentation of the relief was the cause of regional ethnographic diversity which can be seen within a single Balkan nation, no matter which it is.

The Balkan peoples that were for several centuries under the Ottoman, Austro-Hungarian and Venetian rule, after disintegration of the empires created their own national states with differentiated ethnically motivated divisions. From these political and historical conditions centuries-long intolerance and hostility between some of the Balkan peoples arose, and throughout their history they mostly waged wars against each other. Modern history indicates that during the 20th century there were many wars in the Balkans. World War I started there, two Balkan Wars took place and, at the end of the 20th century, regional wars and civil wars within some of the republics of former Yugoslavia were fought. Unfortunately, the Balkans is today still in the shadow of geo history even though the political and economic elites normatively set European integrations as the goal.

Global processes, which caused modernization of the world in the 20th century, did not avoid the Balkan Peninsula, changing its economic and political landscape. This kind of interstate relations arrived in the area of the Balkans with a certain delay, due to strong mutual tensions and confrontations of the 1990s.

Economic development of the Balkan states had little impact on the change of their peoples, because they are prone to divisions and are still burdened by the past in the first decades of the 21st century (Lovčanski, 2005). Even though the Balkan nations are closely linked by multiple historical ties and are directed at each other by their geographic locations and natural resources, economic and cultural ties between them are still weak because the mentality of the population changes slowly. The Balkan states are plagued by numerous common challenges (restricted national markets, economic underdevelopment, high unemployment, corruption, regional polarization and mass influx of population in urban agglomerations, poverty, increasing unemployment), so the interstate cooperation often stays in the background. There are numerous reasons for the absence or poor cooperation between the Balkan states: the non-existence of traditional multilateral cooperation, economic underdevelopment, a number of unresolved issues from the past such as the position and the right of ethnic minorities and the unresolved issue of the return of refugees to their ancestral homes, as well as striking differences among the Balkan states in terms of political, economic, national and other interests (Uvalić, 2013). The peripheral position of the Balkans in relation to the main integrations in Europe also contributed to the inertia of the Balkan states with regard to any kind of cooperation. In order to overcome the problems of the past and increase economic cooperation it is of great importance that the Balkan states strengthen their democratic potential, cooperate in resolving open issues and thus improve security in the Balkans (Šabić et al., 2010; 2011).

The main reasons for the regional cooperation in the Balkans are the following: approaching the European Union in economic and political regard and other forms of the European integrations, the interdependence of the Balkan states-neighbours on each other, foreign pressures, a need for new ways of cooperation in the Balkans due to the disintegration of the former SFR of Yugoslavia, etc.

The Balkan states enter integrations independently or under pressure from major powers, whose interests continue to intersect in this part of Europe. Regional cooperation and integrations of the Balkan states should enable faster solving of political and economic problems (Algieri, 2004). This is the way to make this part of Europe a region of mutual trust, cooperation, stability and above all a region of mergers and permeation. Increased economic growth in the Balkan countries would help intensify regional integrations and integrations with EU. That would reduce poverty, even in the conditions of a more challenging external environment (Bieber, 2012). The main factor of economic growth in small Balkan countries is exports, which largely depends on foreign direct investment. At the beginning of the $21^{\text {st }}$ century, regional initiatives facilitate the regional communication, create a network of different contacts and develop an awareness of the common goals of all Balkan countries. Apart from the general positive effects, the 
mentioned initiatives have not fully helped the countries to ensure European integrations, or led to a fundamental change in the political and economic atmosphere in the region. Overcoming the controversies in the sphere of cultural and interethnic relations in the Balkans includes the promotion of culture of peace and cooperation in all segments of social and political and economic life. Due to its specific geopolitical positions, Serbia must have a more active role in regional cooperation, which would simultaneously achieve both internal and external political and economic stability

The Balkan countries have excellent prerequisites for regional integrations owing to their geographical and cultural closeness. Moreover, in economic, social and political terms, the Balkans is still a heterogeneous area. The countries of the Western Balkans are small both in view of territory and population, undeveloped economically and with small markets, hence they have weak economic power and capacity for self-sustainable and independent economic development (Uvalić, 2013). For that reason, the social-economic recovery of the countries has been realised through strengthening of regional cooperation.

With the aim of attracting more foreign investments and maintaining the economic growth, the states, i.e. the national governments should strengthen the regional integrations and thereby enlarge the effective size of the market. On the national level, it is necessary to establish the order of priorities, while a special attention has to be paid to further development of human potentials. The perspective of the Balkans and broader area of South-East Europe lies in the development of the neighbourly relations and full cooperation, as well as in faster inclusion of the region into European political and economic integration flows. The cooperation of the Balkan states aims at providing a long-lasting stability of the region and suspending all kinds of barriers - from political, over social to cultural ones.

\section{Acknowledgements}

We are grateful to experts for their appropriate and constructive suggestions to improve this article and to our colleagues from the University of Belgrade.

\section{REFERENCES}

[1] Algieri, F. Politika pridruživanja i saradnje, Evropa od A do Š. Fondacija Konrad Adenauer, Bon, 2004.

[2] Anastasakis, O., Bojičić-Dželilović, V. Balkan Regional Cooperation and European Integration. The European Institute, London, 2002.

[3] Balfour, R. and Stratulat, C. The Democratic Transformation of the Balkans, European Policy Centre (EPC): 66, Brussels, 2011.

[4] Balfour, R. and Stratulat, C. Between engagement and cold feet: ten years of the EU in the Western Balkans in E. Prifti (ed.), The European future of the Western Balkans: European Union Institute for Security Studies, Thessaloniki, 2013.

[5] Bartlett, W. and Prica, I. (2011). The variable impact of the global economic crisis in South East Europe. Economics Annals, LVI (191), 7-34.

[6] Bechev, D. (2006): Construction SEE: The Politics of Regional Identity in the Balkans. Ramses Working Paper $1 / 06$.

[7] Bieber. F. The Western Balkans are Dead - Long Live the Balkans! Democratization and the Limits of the EU", and later in V. Džihić and D. Hamilton (eds). Unfinished Business: The Western Balkans and the International Community, Brookings Institution Press, Washington, 2012.

[8] Božilović, N. (2003). Kulturni, etničkli i regionalni identiteti na Balkanu. Filozofski fakultet u Nišu, Niš, 2003.

[9] Bordman, Dž. i dr. Oksfordska istorija rimskog sveta. Polis, Beograd, 1999.

[10] Estrin, S. and M. Uvalić (2013). Foreign Direct Investment into Transition Economies: Are the Balkans Different?", LSE Europe in Question, Discussion Paper Series, LEQS Paper No. 65.

[11] Gowan, P. (1995). Neo-Liberal Theory and Practice for Eastern Europe, New Left Review 213, 3-60.

[12] Grčić, M. (2005). Balkan kao kulturni subkontinent Evrope. Glasnik SGD, 85 (1), 209-218.

[13] Grčić, M. (2008). Cvijićeva percepcija geografskog položaja Srbije. Glasnik SGD, 88(2), 3-12.

[14] Vujadinović, S. et al. (2013). Asylum Seekers from Serbia and Problems of Returnees: Why Is Serbia in the World Top in the Number of Asylum Seekers? Two Homelands 37, 53-68.

[15] Vujadinović, S. et al. (2011). Years of Refugee Life in SerbiaChallenges for a New Beginning: Stay or Return Home? Trames15, 3, 235-258.

[16] Lopandić, D. Regionalne inicijative u Jugoistočnoj Evropi. IMPP, EPUS, Beograd, 2001.

[17] Lopandić, D. Inicijative i oblici multilateralne saradnje u jugoistočnoj Evropi, Jugoistočna Evropa 2000 - Pogled iz Srbije, Stubovi kulture, Beograd, 1999.

[18] Lovčanski, A. Uporedni pregled tranzicionih procesa $\mathrm{u}$ zemljama Zapadnog Balkana. BOŠ, Beograd, 2005.

[19] Magen, A. (2007). Transformative Engagement Through Law, European Journal of Law Reform 9(3), 361-393.

[20] Popescu Nescseti, B. S. (1994). Political and economic cooperation between the Balkan countries, Eurobalkans, (16), 45 .

[21] Popović, G. Evropska unija. Regionalna politika, Beograd, 2006.

[22] Cvijić, J. Balkansko poluostrvo i južnoslovenske zemlje. Osnovi antropogeografije, Beograd, 1922.

[23] Šabić, D. i dr. (2010). Globalni i regionalni aspekti razvoja Srbije i Balkana - događaji iz prošlosti kao pouka za budućnost. Glasnik SGD XC (1), 159-170. 
[24] Šabić, D. i dr. Izazovi globalizacije - socioekonomske i kulturoloske prilike u Srbiji. Treći kongres geografa, Banja Luka, 2011.

[25] Šabić, D. et al. (2012). The Impact of FDI on the Transitional Economy in Serbia - Changes and Challenges, Acta Polytechnica Hungarica, 9(3), 65-84.

[26] Šabić, D. i Vujadinović, S. Regionalna geografija Evrope. Geografski fakultet u Beogradu, Beograd, 2014.

[27] Šabić, D. et. al. Geographical research of Isolation and Separation Features of the Balkans in the time of Cvijic and Today. SASA: 150th Anniversary of Jovan Cvijić's birth, Belgrade, 2015.

[28] Uvalić, M Regionalism in Southeast Europe. in P. Della Posta,
M. Uvalić and A. Verdun (eds.). Globalization, Development and Integration: A European Perspective, Palgrave Macmillan, Basingstoke, 2009.

[29] Uvalić, M. The Economic Development of the Western Balkans since Thessaloniki. in E. Prifti (ed.). The European Future of the Western Balkans. European Union Institute for Security Studies, Paris, 2013.

[30] Veremis, T. The Balkans in search of multilateralism. Corfou, Athens: The EC and the Balkans, Proceedings of the Conference, 1993.

[31] World Bank Group - South East Europe, Resilient Growth Amid Rising Risks, Regular Economic Report, No. 10, 2016. at www.worldbank.org/eca/seerer. 